\title{
PELATIHAN PENGGUNAAN MENDELEY UNTUK REFERENSI DALAM MENULIS KARYA ILMIAH BAGI GURU SMA HANDAYANI PEKANBARU
}

\author{
Pahmi*, Ardiya, Wandi Syahfutra, Agung Prasetyo Wibowo, \\ Siti Niah, Prih Febtiningsih \\ Prodi Pendidikan Bahasa Inggris, Fakultas Keguruan dan Ilmu Pendidikan \\ Universitas Muhammadiyah Riau \\ email: pahmi@umri.ac.id
}

\begin{abstract}
The community service undertaken aims to provide training to the teachers at Handayani Senior High School about the importance of producing quality scientific papers. Specifically, this training provides the opportunity for participants to practice directly how to write scientific papers using Mendeley software for reference used in the paper. Mendeley is a computer and web program developed by Elsevier to manage and share research papers, search for research data, and work together online. Posts made with Microsoft Word, Open Office or LaTex can be linked to Mendeley software so that citations and reference lists (bibliography) can be arranged automatically. To achieve the goals and targets of this community service activity (PPM), the implementers use the lecture, discussion and practicum methods so that the trainees can easily understand the material provided in the training. The activities carried out involve the teachers at Handayani Pekanbaru Senior High School as participants. The response from the participants is positive which can be seen from their active participation during the activity. They also find the training really useful to help them become more productive teachers by writing more scientific papers using Mendeley.
\end{abstract}

Keywords: Community Service, Scientific Paper, Reference, Mendeley

\begin{abstract}
Pengabdian pada masyarakat yang dilakukan bertujuan untuk memberikan pelatihan kepada para guru SMA Handayani Pekanbaru akan pentingnya menghasilkan karya tulis ilmiah yang berkualitas. Secara specifik, pelatihan ini memberikan kesempatan kepada para peserta untuk praktek langsung bagaimana menulis karya ilmiah dengan menggunakan software mendeley untuk referensi rujukan yang di gunakan dalam karya tulis. Mendeley merupakan program komputer dan web yang dikembangkan Elsevier untuk mengelola dan berbagi makalah penelitian, mencari data penelitian, dan bekerja sama secara daring. Tulisan yang dibuat dengan Microsoft Word, Open Office atau LaTex bisa dihubungkan dengan software Mendeley sehingga sitasi dan daftar referensi (bibliography) bisa disusun secara otomatis. Untuk mencapai tujuan dan target dari kegiatan pengabdian pada masyarakat (PPM) ini, maka pelaksana menggunakan metode ceramah, diskusi, dan praktikum agar peserta pelatihan dapat mudah memahami materi yang diberikan pada pelatihan tersebut. Kegiatan yang dilaksanakan diikuti oleh para guru di SMA Handayani Pekanbaru. Peserta merespon kegiatan ini dengan sangat positif yang bisa dilihat dari keaktifan mereka selama kegiatan berlangsung. Lebih jauh mereka merasa pelatihan sangat berguna dalam membantu mereka menjadi guru yang lebih produktif untuk menulis lebih banyak karya ilmiah menggunakan aplikasi Mendeley.
\end{abstract}

Kata Kunci: Pengabdian kepada Masyarakat, Karya Ilmiah, Referensi, Mendeley 


\section{PENDAHULUAN}

Salah satu aspek penting dalam kehidupan manusia adalah pendidikan. Dalam pendidikan manusia dapat belajar banyak hal dan pengetahuan untuk menjawab tuntutan zaman dan arus globalisasi yang kian menantang. Untuk dapat memenuhi tuntutan dan perubahan tersebut setiap pribadi diminta menyiapkan diri sedini mungkin yang diproses melalui tahap-tahap pendidikan. Maju mundurnya dunia pendidikan sangat tergantung pada pengelolaan pendidikan, tenaga pengajar, peserta didik dan sarana yang digunakan dalam Pendidikan tersebut.

Dalam upaya meningkatkan kualitas diri para pendidik, telah dilakukan beberapa upaya seperti studi lanjut, mengikuti seminar, dan menulis karya ilmiah. Khusus menulis karya ilmiah, para guru sudah seharusnya memiliki kemampuan menulis yang baik. Untuk mulai menulis, para pendidik bisa mulai dari sesuatu yang sederhana dan informal, misalnya jurnal/diari kegiatan sehari-hari (Santosa, 2002).

Seperti halnya sekolah-sekolah Menengah Atas lain di kota-kota besar di Indonesia, para guru SMA Handayani Pekanbaru di harapkan untuk terus meningkatkan kompetensi dengan menghasilkan karya tulis ilmiah yang berkualitas. Olehkarena itu, setiap guru di motivasi secara terus-menerus yang pada akhirnya akan meningkatkan mutu pengajaran dan pengelolaan sebagai upaya untuk menuju sekolah yang mampu bersaing secara nasional maupun internasional nantinya. Pengabdian Kepada Masyarakat "Pelatihan Penggunaan Mendeley untuk Referensi dalam Menulis Karya Ilmiah bagi Guru SMA Handayani Pekanbaru", merupakan salah satu upaya yang dapat dilakukan untuk meningkatkan kemampuan guru dalam menghasilkan karya tulis ilmiah yang berkualitas.
Berkaitan dengan komitmen SMA Handayani untuk meningkatkan kemampuan guru dalam menulis karya ilmiah, bantuan penanganan yang terencana dan terprogram kiranya sangat dibutuhkan. Untuk itulah program ini dirancang sebagai upaya untuk memberikan sumbangan yang bermanfaat bagi para guru. Pengabdian Kepada Masyarakat ini diharapkan dapat membantu guru agar termotivasi untuk selalu meningkatkan kompetensi diri melalui karya tulis ilmiah.

Keterampilan menulis sangat dibutuhkan para guru dalam upaya meningkatkan kualitas pendidikan. Menurut beberapa penelitian, menulis merupakan keterampilan berbahasa paling tinggi sekaligus paling langka digunakan dalam komunikasi (Anshori, 1996). Akan tetapi, setelah dilakukan observasi pada beberapa guru di SMA Handayani Pekanbaru, masih banyak guru yang belum benar-benar memahami cara penulisan karya ilmiah yang baik termasuk bagaimana cara membuat kutipan daftar pustaka/referensi dengan menggunakan sistem aplikasi komputer, selama ini masih menggunakan sistem manual.

Persoalan ini tentu sangat penting untuk di cari solusinya, karena tuntutan didunia publikasi karya ilmiah pada saat ini khususnya jurnal-jurnal yang sudah memiliki akreditasi $\mathrm{A} / \mathrm{B}$ dan jurnal intenational sudah wajib untuk menggunakan aplikasi khusus sebagai syarat agar lulus dan diterima pada jurnal-jurnal tersebut. Mendeley merupakan aplikasi popular yang digunakan sebagai pengelolah daftar pustaka dengan 2.8 juta pengguna dan 535 juta dokumen (Costas, Zahedi, \& Wouters, 2015). Menurut (Fairclough \& Thelwall, 2015) mendeley dapat menjadi media untuk membagai artikel kepada orang lain dan dapat mudah untuk digunakan dalam mengutip untuk mendukung penelitan. Mendeley juga 
dapat menjadi cara untuk meningkatkan dampak artikel dengan cara mengutipnya dengan menggunakan mendeley (Mohammadi, Thelwall, Haustein, \& Larivi, 2015).

Melihat hal di atas, sangat penting di adakan pelatihan bagi guru tentang penulisan karya ilmiah menggunakan mendeley. Dari beberapa penelitian tentang workshop/pelatihan dari Agusta (2013), pelatihan memiliki pengaruh positif terhadap kinerja karyawan CV. Haragon Surabaya. Sedangkan menurut Wahyudi (2015), setelah dilakukan workshop kemampuan guru KKG Gugus 02 Kecamatan Sumbermalang mengalami peningkatan. Pada penelitian yang dilakukan oleh Siagian (2015) dan Ridwan (2017) juga menunjukan bahwa pelatihan dapat meningkatkan kemampuan kinerja karyawan. Olehkarena itu, pelatihan ini sangat penting guna meningkatkan kemampuan menulis guru SMA Handayani Pekanbaru. Meningkatnya produktifitas menulis guru tentu akan berdampak pada peningkatan mutu pendidikan.

\section{METODE PENGABDIAN}

Dalam pelaksanaan Pengabdian kepada Masyarakat ini, materi dirancang sesuai dengan kebutuhan pihak SMA Handayani. Materi yang disampaikan pada "Pelatihan Penggunaan Mendeley dalam Menulis Karya Ilmiah bagi Guru SMA Handayani Pekanbaru" memiliki poin utama yaitu cara menggunakan Mendeley sebagai software gratis yang bisa di gunakan para guru untuk memudahkan mereka dalam menulis karya ilmiah. Hal ini sangat penting karena guru sudah seharusnya produktif dalam menulis. Dengan mengetehui cara menggunakan Mendeley ini diharapkan guru semakin giat dalam melakukan penelitian dan mempublikasikan karya mereka dalam bentuk jurnal. Adapun metode yang digunakan dalam kegiatan pelatihan ini adalah metode presentasi, diskusi, dan praktikum. 1) Metode presentasi digunakan untuk menyampaikan materi secara rinci tentang penulisan karya ilmiah dengan menggunakan aplikasi Mendeley. 2) Metode diskusi digunakan untuk mengakomodasi pertanyaan tentang topik pada materi yang telah disampaikan. 3) Metode praktikum digunakan untuk memberikan pengalaman secara langsung kepada peserta bagaimana menggunakan aplikasi Mendeley.

Dalam pelaksanaannya, kegiatan ini diawali dengan perkenalan antara Tim pelaksana dengan peserta pelatihan yaitu para guru SMA Handayani Pekanbaru, yang dilanjutkan dengan penyampaian materi kepada peserta. Setelah itu diakhiri dengan review singkat terhadap kegiatan yang telah dilaksanakan. Kegiatan pengabdian kepada masyarakat ini dilakukan pada bulan Juli-September 2018. Adapun rancangan jadwal pelaksanaan kegiatan pengabdian adalah sebagai berikut.

Tabel 1: Jadwal Kegiatan

\begin{tabular}{|c|l|l|l|}
\hline \multirow{2}{*}{ No } & \multicolumn{1}{|c|}{ Kegiatan } & \multicolumn{2}{c|}{ Bulan } \\
\cline { 3 - 4 } & Juli & $\begin{array}{c}\text { Agus- } \\
\text { Sep }\end{array}$ \\
\hline 1 & $\begin{array}{l}\text { Lokakarya Dasar- } \\
\text { dasar } \\
\text { Penulisan karya } \\
\text { ilmiah }\end{array}$ & & \\
\hline 2 & $\begin{array}{l}\text { Lokakarya } \\
\text { penggunaan mendeley } \\
\text { dalam penulisan karya } \\
\text { ilmiah }\end{array}$ & & \\
\hline 3 & $\begin{array}{l}\text { Lokakarya teknik } \\
\text { publikasi karya tulis } \\
\text { ilmiah pada jurnal } \\
\text { nasional dan } \\
\text { internasional }\end{array}$ & & \\
\hline
\end{tabular}

\section{HASIL DAN PEMBAHASAN}

Kegiatan pengabdian kepada masyarakat ini mendapatkan sambutan yang sangat positif dari pihak mitra yakni SMA Handayani Pekanbaru. Hal 
ini dikarenakan program ini sesuai dengan kebutuhan mereka untuk menjadi guru yang produktif dalam menghasilkan karya ilmiah. Pelatihan ini di ikuti oleh para guru yang berpartisipasi secara aktif dalam mengikuti seluruh proses kegiatan. Pelatihan ini dapat dilihat pada gambar 1.

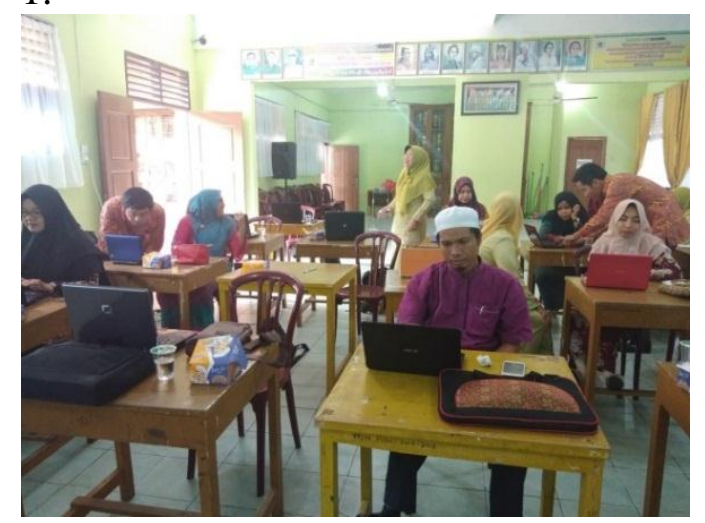

Gambar 1. Suasana Kegiatan

Seluruh peserta pelatihan memiliki motivasi yang tinggi yaitu dengan sangat antusianya mereka dalam kegiatan pelatihan. Hal tersebut mengindikasikan bahwa adanya kesadaran para peserta pelatihan tentang pentingnya menulis karya ilmiah yang dalam hal ini sangat terbantu dengan menggunakan aplikasi Mendeley. Seusai pelatihan, peserta memberikan kesan yang positif dan berharap pelatihanpelatihan berikutnya bisa di adakan lagi di tempat mereka.

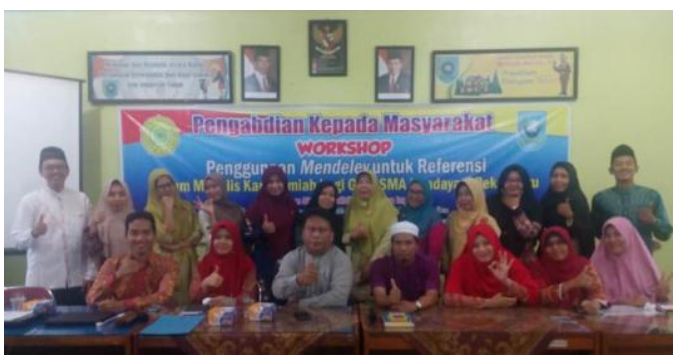

Gambar 2. Para peserta pelatihan

Peningkatan kemampuan menulis karya ilmiah menjadi tuntutan bagi setiap guru pada saat ini. Hal ini menjadi wadah peningkatan kompetensi guru yang pada akhirnya akan berdampak pada perbaikan mutu pendidikan peserta didik. Sehingga dengan adanya program pelatihan ini, para guru merasa sangat terbantu untuk menjadi guru yang lebih produktif. Secara singkat, berdasarkan hasil yang didapat dari kegiatan pengabdian pada masyarakat (PPM) yang telah dipaparkan, bisa dilihat bahwa kegiatan pengabdian ini mendapat respon yang sangat baik dari para peserta. Para guru SMA Handayani Pekanbaru sangat aktif dalam setiap sesi kegiatan. Kegiatan yang diikuti oleh peserta pengabdian berjalan dengan baik, dimana terjadinya kerjasama yang baik dan proaktif diantara para peserta yang sangat antusias dalam berdiskusi tentang materi yang sudah diberikan pada pelatihan tersebut. Keberhasilan kegiatan pengabdian ini terlihat dari adanya kemauan atau kesungguhan yang tinggi yang ditunjukkan oleh peserta melalui kegiatan selama kegiatan berlangsung. Hal ini menunjukkan bahwa mereka merasakan manfaat dari adanya kegiatan pengabdian ini sehingga mereka menganggap pentingnya penggunaan aplikasi Mendeley dalam membantu mereka menulis karya ilmiah.

\section{SIMPULAN}

Peningkatan kompetensi guru bisa dilakukan dengan berbagai cara, salah satunya dengan aktif melakukan penelitian dan di tuangkan dalam karya tulis ilmiah. Pada prosesnya para guru masih menggunakan metode konvensional ketika menulis karya ilmiah khususnya pada bagian pengutipan. Membantu guru dalam memudahkan mereka menulis karya ilmiah merupakan tanggung jawab bersama. Olehkarena itu, program pengabdian kepada masyarakat tentang bagaimana menulis karya ilmiah menggunakan aplikasi Mendeley sangat diperlukan. Dengan menyampaikan materi tentang penulisan karya ilmiah 
dan penggunaan Mendeley, para peserta menjadi terbantu yang tentu saja akan mendorong mereka untuk lebih produktif menghasilkan karya ilmiah.

Bagi tim pelaksana dari Program Studi Pendidikan Bahasa Inggri UMRI juga dapat menjalankan catur dharma perguruan tinggi dimana salah satu perannya adalah dengan pengabdian kepada masyarakat ini.

\section{UCAPAN TERIMAKASIH}

Pelaksanaan kegiatan Pengabdian kepada Masyarakat ini tentunya tidak akan terlaksana sesuai rencana jika tanpa bantuan dari berbagai pihak. Oleh karena itu maka penulis mengucapkan terima kasih kepada seluruh pihak yang telah membantu secara materil dan moril sehingga kegiatan pengabdian ini dapat terlaksana dengan baik. Adapun ucapan terima kasih tersebut ditujukan kepada:

1. Rektor UMRI

2. Ketua LPPM UMRI

3. Dekan FKIP UMRI

4. Ketua Program Studi Pendidikan Bahasa Inggris

5. Kepala SMA Handayani Pekanbaru

6. Majelis Guru SMA Handayani Pekanbaru

\section{DAFTAR PUSTAKA}

[1] Agusta, L. (2013). Pengaruh pelatihan dan motivasi kerja terhadap kinerja karyawan CV Haragon Surabaya. Agora, 1(3), 1399-1408.

[2] Anshori, D. S. (1996). Peningkatan Kemampuan Menulis Mahasiswa Melalui Model Workshop dalam Perkuliahan Kepenulisan pada Program Nonkependidikan Jurusan Pendidikan Bahasa dan Sastra Indonesia FPBS UPI. Action Research, 5.

[3] Costas, R., Zahedi, Z., \& Wouters, P. (2015). Do "altmetrics" correlate with citations? Extensive comparison of altmetric indicators with citations from a multidisciplinary perspective. Journal of the Association for Information Science and Technology, 66(10), 2003-2019. https://doi.org/10.1002/asi.23309

[4] Mohammadi, E., et al, V. (2015). Who reads research articles? An altmetrics analysis of Mendeley user categories. Journal of the Association for Information Science and Technology, 66(9), 1832-1846. https://doi.org/10.1002/asi.23286

[5] Ridwan, A. S. S. (2017). Peningkatan Mutu Dikalangan Guru Sd Dengan Kemampuan Penyusunan Proposal Ptk. Jurnal Penjaminan Mutu, 3(1), 23-30.

[6] Santosa, M. H. (2002). Pemanfaatan Blog (Jurnal Online) Dalam Pembelajaran Menulis. Universitas Pendidikan Ganesha, 1-34.

[7] Siagian, S. S. I. 1. (2015). Pengaruh Pelatihan, Kepuasan Kompensasi, Motivasi Dan Disiplin Kerja Terhadap Kinerja Karyawan. Jurnal Ilmu Dan Riset Manajemen, 4(9), 120.

[8] Wahyudi, I. (2015). Meningkatkan kemampuan guru dalam menyusun tes hasil belajar akhir semester melalui workshop di kkg gugus 02 kecamatan sumbermalang tahun 2014/2015. Pancaran, 5(1), 67-82. 